\title{
Evaluation Model in the Branch of Virtual Education of “Universidad Manuela Beltrán” Bogotá-Colombia
}

\author{
J. López
}

\begin{abstract}
This Paper presents the evaluation model designed for the virtual education branch of The "Universidad Manuela Beltrán, Bogotá - Colombia". This was the result of a research, developed as a case study, which had three stages: Document Review, observation, and a perception survey for teachers. In the present model, the evaluation is a cross-cutting issue to the educational process. Therefore, it consists in a group of actions and guidelines which lead to analyze the student's learning process from the admission, during the academic training, and to the graduation. This model contributes to the evaluation components which might interest other educational institutions or might offer methodological guidance to consolidate an own model.
\end{abstract}

Index Terms-Model, evaluation, virtual education.

\section{INTRODUCTION}

The purpose of this paper is to present the results of the PHD research project learning evaluation in virtual environments, a case study in the virtual education branch UMBVIRTUAL, (Universidad Manuela Beltrán, Bogotá Colombia). This project aims to design an evaluation model for UMBVIRTUAL, taking into consideration that some of the features could be cross-cutting to different educational sceneries, therefore, could be applied in different fields.

The Manuela Beltrán University is an educational institution with 39 years of experience in Colombia. Here, the virtual branch projectstarted; now, we count with 10 years of experience in the Colombian educational field at different levels, such as undergraduate and graduate programs and non-formal education programs.

\section{PROBLEM}

The evaluation is perceived as the final step in the academic process, where the teacher gives a qualitative and quantitative concept about a task or duty, or something done by the student. This has reduced its area of action, because this "action", has been developed along the whole academic process. Thus, the evaluation must be analyzed since the moment of setting the competences, topics, activities, and the evaluation criteria for each course, until the feedback, the learning strategies and the impact in the academic context" [1]. Reducing the evaluation to a qualitative or quantitative concept at the end of the academic process generates an integrality loss, which has to exist along all the process, and it

Manuscript received August 20, 2014; revised November 10, 2014.

Javier López Martínez is with UNED, Universidad Manuela Beltrán Virtual, Colombia (e-mail: javier.lopez@umb.edu.co). also impacts negatively in the quality of education.

Some of the reasons that evaluation has been reduced are: 1) The pedagogical models don't define the evaluation as a cross cutting matter in the educational process. 2) We can state that "regularly, teaching is not their main occupation, but one that they have selected after graduating. [2]. Hence, competences to evaluate haven't been previously acquired, but are developed during the teaching practice. 3 ) It is necessary "to understand the role that each participant takes in the evaluation; to know that the evaluation results depend on the decisions that we take in relation to the reason we are evaluating for, and those, have to suggest the different evaluating sceneries" [3].

To conclude, it's important to mention that generally speaking, the evaluation is not an easy task, it implies the assessment of competences and not always it's possible to obtain the required information to complete it. It also occurs, that the teacher doesn't provide the information that requires to create a proper evaluation and, evaluates "conventionally, with improper instruments and without informing the students about the evaluation terms and conditions" [4].

\section{JUSTIFICATION}

The evaluation is a primarily matter in the academic scenery for different reasons. One of them, is, that would be "a little coherent to talk about quality without talking about evaluation, because stating that something has quality, has to be measured and compared it with an ideal model to elaborate a judgment about the object or subject evaluated [5]. Another reason, it that "the evaluation is a powerful tool in the teaching and learning improvement" [6].

From an administrative perspective, the importance of evaluation could be seen in the discussion guidelines from Plan Decenal de Educación Acciónsobre la Evaluación del Aprendizaje yCalidad de la Educación, 2008, that is proposed by the ministry of education, where it is established that "the evaluation, with all its complexity is a fundamental tool for education at all levels" [7].

Now, in a virtual educational context, this is even more complicated, because at the beginning it is necessary to ask if it is convenient or not, to continue with the same evaluation structure that we find at "in-person class". About this, [8] consider that "the method of every mean of evaluation, has to take into consideration the Specific codes in communication. In this sense, it is necessary to exceed the traditional perspectives in the evaluation, taking into account that the evaluation in Virtual education, has to diversify, suggesting different evaluation alternatives for all of this".

Based on this, it is possible to establish that an evaluation 
model convenient for virtual education sceneries is required, for all the new means of communications that emerge and are used there. This model, has to be consolidated as the foundation to manage, and foment the quality of the academic process.

\section{LITERATURE REVIEW}

The concept of evaluation has different definitions that could be grouped from two fundamental questions, what to evaluate? Related to the object of academic evaluation, what to evaluate for? This determines the purpose of the evaluation.

Thereby, about what to evaluate? The analysis of this "the evaluation object" goes around the cognitive skills, the objective achievement, and the value of learning, "the educational processes since the learning needs" [9], among others. And, about ¿what to evaluate for? The educational context, suggests among other reasons: the improvement of academic quality and the student guidance in the learning process, "the comprehension, planning, and improvement of the academic programs" [10]. About this overview, the arrival of internet during the last years, has created fundamental changes in the form of understanding the educational processes, because, the virtual procedures modify the relation among students, tutors and the learning environments, which demands from the participants a long term perception, and the adaptation to the virtual environments for the future [11], cognitive flexibility, constant updating, and the adaptation of educational standards, among other different aspects.

This phenomenon implies changes in the evaluation processes in virtual environments, as well as in the academic, organizational and structural aspects. Although, these are relevant, they are related to the academic quality, and in line with the educational model, frequently related to constructivist perspectives [12]. The innovation of virtual platforms, creates a substantial effort, so that it counts with updated information about the successes and failures [13]. The learning simplicity and its effectiveness [14] and the coherence of the process, in terms that the academic criteria is above the technological and the esthetic, where knowledge could be built - not simply knowing about something- and that the educational proposal will be deep and attractive [12].

Perceived in this form, the evaluation is not something external and punctual, but, it takes part continuously in the learning - teaching process and it becomes a part that provides a constant information for the adjustment of the educational support that offers the teacher to the students. Through the creation of educational contexts. In terms of [15], from a constructivist point of view, it is important to know, what the students could do by themselves, and what they could improve with the assistance and orientation given by the tutor. The regulating role that the evaluation acquires in the learning - teaching process have to be given from the beginning to the end of this, which would question the classic vision of evaluation, that differentiates the introductory evaluation, formative evaluation and summative evaluation.

In addition, the evaluation in virtual environments demands the usage of a situational model, in which learning is developed from the student's participation in specific groups of social and professional practice; therefore, the students develop their identities through the immersion in a real or simulated environment of social practice [16]. To conclude, It can be mentioned that the evaluation in virtual environments generates significant changes with regard to the traditional evaluation, because into consideration the learning result, but it is converted in a process, which plans, identifies, describes, defines, promotes, foments, orientates, controls, and values the learning, understood, at the same time, as a cultural process of permanent learning construction and reconstruction. Thus, the learning environments should be constituted interactively, to share ideas and give feedback from the peers [17].

\section{METHODOLOGY}

We set out a case study, where the subject of analysis is the Virtual Education branch of "Manuela Beltrán University, Bogotá - Colombia (UMB VIRTUAL)". Where different instruments to collect information and techniques of analysis were used, which, complemented the information addressing from different perspectives, Theoretical, Administrative and educational.

The first stage was guided to the theoretical fundamentals, in which, some categories of analysis were defined, these were the foundations for the elaboration and application of some instruments, and for the consolidation of the evaluating model. This process started by completing bibliographic records, and then the content was analyzed to define the categories, by matching coincidences, divergences, and importance, supported by different authors. The categories were defined in, goals and purposes of the diploma, functions of the evaluation for the participants of the process (students teachers- institution and society); Verification of the results (Anticipated and unanticipated), Feedback, Establishment of the initial state, relation with the professional activity, learning context, declaratory and procedural knowledge, virtual room organization and educational behavior.

For the second stage we classified the case of study: The virtual UMB. The data was collected from the observation and registration of field notes by the educational coordination in the virtual UMB, guided by the UMBVIRTUAL director. This started with conceptual categories, which were previously defined, and the objective was to determine the model that had been using in this Branch. This stage, allowed the identification of the components to strengthen, and those that were guided properly, from an institutional and administrative perspective.

In the third stage, a survey was the designed instrument to gather information, it was addressed to approximately 600 teachers from the "Universidad Manuela Beltrán". These teachers were selected due to their vast knowledge about the topic of evaluation, and they are evaluating constantly the learning acquisition in their rooms, from these institutional guidelines. Considering that the case of study is "UMBVIRTUAL", thus, teachers who teach virtually, are the ones who carry out their functions as virtual teachers and some from the traditional branch of the University, who have experienced teaching virtually.

It wasn't defined a specific sample, because all the teachers were contacted and we worked with the answers obtained from them. The scenery used to contact the teachers was our 
LMS (Virtualnet 2.0) and a diploma course for all the group of teachers which were studying it, as a part of the formation programs that the UMB offers for its group of teachers, and as a formal plan of continuous educational formation. It was used a survey to collect the data, which was created based on the categories that were previously stated by introducing some questions based on those. The survey was guided to obtain information about the perception of the teachers referring to the categories in the educational training context. The survey was applied in two moments, at the beginning and at the end of the diploma course, this, was sent to all the teachers, obtaining 128 replies in the first moment, and 119 in the second one.

The three stages allowed us to collect information from different sources. This, was organized based on three different stages, the first one was described in bibliographic records, and based on these a document was created where the categories were established. In the second one in field notes, and a document that describes the model evaluation components that in practice are being used at UMB VIRTUAL. The third, in questionnaires uploaded in Google Drive, with a document that describes the statistical results for each answer which summarizes the comments stated by the participants.

To conclude, and based on the results of the descriptive document with the current model and the document that summarizes the survey result, we proceed to elaborate the evaluation model for UMB VIRTUAL. Additionally, and based on the analysis from the three stages, some recommendations are offered to implement evaluation strategies about learning in virtual environments.

\section{RESULTS}

To continue, the evaluation model of UMB Virtual is presented below (Fig. 1), which is divided in three parts: Evaluation of components, self-assessment process and performance, social effect. This design is the result to the research work.

\section{A. Evaluation of Competences}

It is understood as the systematic and planned process of assessment that is applied based on the knowledge, abilities, skills, and levels of achievement that the student is accomplishing progressively during the process. The evaluation, is established as a constant development, organized and systematic, that collects information to remark the requirements of validity, dependence, reliability, usefulness by diverse strategies, methods and instruments. With this, it focuses in providing information, create valuations about the learning - teaching process and resides in the group of variables of personal, familiar and academic contributions, that have an impact on the performance, and contributes with the balance of the evaluation

\section{B. Self-Assessment and Performance}

The self-assessment constitutes an important tool, which is used by UMB VIRTUAL to reflect about the actions that have been taken place at here, and the obtained results. From this reflection, it is possible to identify both, positive features, and those which should be improved, and with this, propose, implement and monitor all the actions to improve, in order to benefit the programs, by giving to the group, the opportunity to analyze the situation, introduce gradual improvements, and evaluate the results.

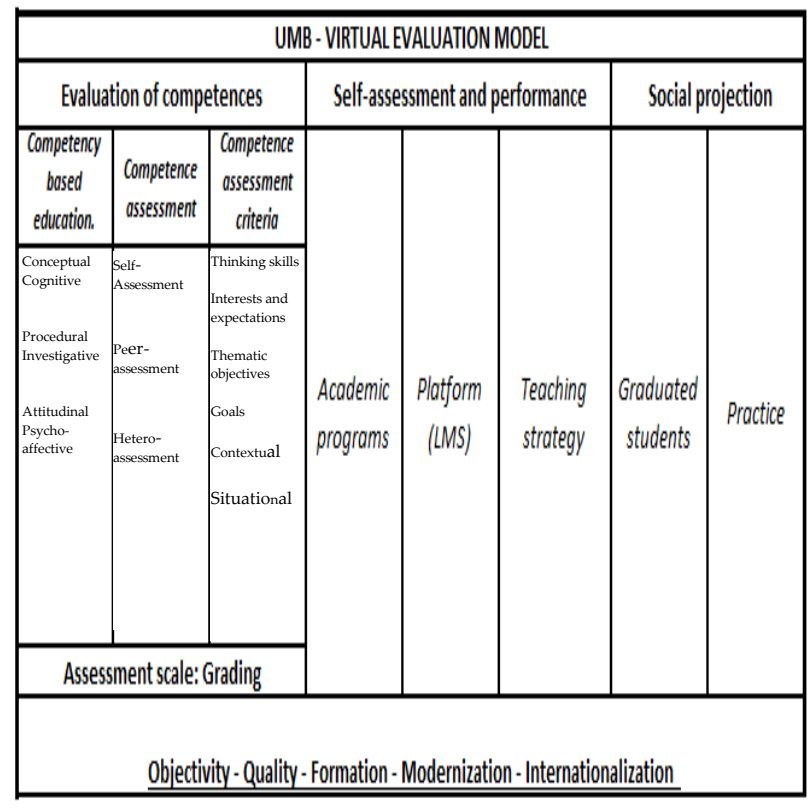

Fig. 1. UMB virtual evaluation model.

\section{Social Projection}

Developed along the process, the social projection shows, the Education as the Socializing process that ensures learning and knowledge building, this, aims to educate independent and free individuals, capable of taking responsibility for themselves and acting accordingly to their needs taking into account the importance of their peers and recognizing them as a part of their education. UMB VIRTUAL has accordingly to this, the continuous planning, designing, and execution of strategies, actions and activities related to the guidelines of our Institutional Education Project, contributing to motivate and strengthen the professional projection of our graduates, generating teamwork, and strong solid networks of comradeship, friendship and learning, with the purpose of a better quality of life.

\section{Quality Process}

This is the evaluation system at the UMB VIRTUAL, it is constituted as the cornerstone to reach the academic excellence, committed with the academic quality and focused on international standards, which strengthen the Virtual Education process.

\section{CONCLUSION}

Submission the current evaluation model, is a mixture of different actions and guidelines which let us know how the students learning process is, from the admission, during the academic training, and until the graduation. In practice, the actions starts from the purpose of academic competences, then, with the topic definition, and the activities and content structure, and finally the evaluation criteria. It is important to take into consideration the mixture of all these elements. An evaluation process that starts with an introductory evaluation, formative evaluation and summative evaluation guarantees 
that the students perceive that are obtaining properly the competence acquisition and understanding that has been planned from the rubrics, the feedback, collaborative work until the final qualitative and quantitative assessment.

The theoretical foundation that stands this model, associates the significant learning, the situated learning, the collaborative work and connectivism. This mediated by ICT and communication, which takes us to an academic process supported by audiovisual material, multimedia material and synchronous and asynchronous communication tools, that offer the proper information for the evaluative process.

The virtual learning evaluation model proposed at "UMB VIRTUAL" is a model designed to demonstrate how the objectives are achieved, which have been planned from the curriculum, then are adapted and displayed graphically to make them pleasant for students, these are used by the teachers accordingly to the group, students and other different variables, taking into account this, the teachers optimize the material taking into consideration their point of view and own experience in the academic field. Then, through the collaborative work, and based on the academic activities is integrated with students - teachers and vice versa, to clarify and consolidate the knowledge in students. Therefore, the Virtual Evaluation Model constitutes an important source of information in which, we pretend to develop all the necessary improvements for the academic process and the environment which takes part of it, as well as the completed academic processes.

It is possible that the evaluation in virtual environments has the same problems as "in-person class", and sometimes, the same success that in traditional learning environments. The question is not only the evaluation, or the technical aspects, but the context of the evaluation, which has to be immersed in an educational model, to find learning and teaching of quality

In the virtual learning environments, the evaluation has to incorporate technical conditions to satisfy different aspects and variables, which allow the students to have relevant information for their process. in fact, it demands more requirements for the designers and tutors, for the proper adjustment of the material, taking into account all the different ICT tools that we have nowadays, and all the devices and technology approachable for students; This, involves a change of role from the teachers into mediators and designers of proper learning environments, breaking the model of traditional education.

An evaluation model has to aim to renovate how the students truly are as individuals, their personal environment as a whole, including their peers. There, it is shown a good evaluation model, and a good academic process. The biggest barrier is the information that is required to carry out an important and significant problem called evaluation.

\section{REFERENCES}

[1] A. Mena and J. López, "La evaluación en entornos educativos virtuales," Primer Congreso Internacional de Pedagogía y didáCtica, Universidad Autónoma de Colombia, 2013.

[2] I. Guzmán, R. Marín, G. Zesati, and R. Breach. (2012). Desarrollar y evaluar competencias docentes: estrategias para una práctica reflexiva. Voces y Silencios: Revista Latinoamericana de Educación. [Online]. (3).

Available:
http://vocesysilencios.uniandes.edu.co/index.php/vys/article/viewFile $/ 110 / 291$.

[3] C. Suárez. (2008). Diagnóstico sobre el estado de la práctica evaluativa. Retroalimentación constante al alumno, realizada por docentes/tutores de programas virtuales, en la Universidad Colegio Mayor de Cundinamarca. Cuadernos de la maestría en docencia e investigación Universitaria. Universidad Sergio Arboleda. [Online]. (1). Available: de:http://www.usergioarboleda.edu.co/docencia/cuadernosMaestria.p df\#page $=127$

[4] L. Villardón. (2006). Evaluación del aprendizaje para promover el desarrollo de competencias. Educatio siglo XXI. [Online]. (24). Available:

http://revistas.um.es/index.php/educatio/article/viewFile/153/136

[5] G. Egido. (2005). Reflexiones en torno a la evaluación de la calidad educativa. Revista Tendencias Pedagógicas. [Online]. (10). Available: http://www.tendenciaspedagogicas.com/Articulos/2005_10_01.pdf.

[6] M. Jané. (2005). Evaluación del aprendizaje. Problema o herramienta? Revista de Estudios Sociales. [Online]. (20). Available: http://www.scielo.org.co/scielo.php?pid=S0123-885X200500010000 $7 \&$ script=sci_arttext

[7] Ministerio de Educación Nacional. (2008). Lineamientos de discusión plan decenal en acción. Evaluación del aprendizaje y calidad de la educación. [Online]. Available: http://www.plandecenal.edu.co/html/1726/articles-160745_archivo_p df.pdf

[8] S. López and N. Tessio. Evaluación en entornos virtuales: Reflexiones a partir de experiencias sincrónicas en la Licenciatura en Tecnología Educativa de la UTN. Facultad Regional Avellaneda. Universidad Tecnológica Nacional. [Online]. Available: http://puntodeencuentro.utn.edu.ar/wp-content/uploads/2011/03/TES ET_p035a050.pdf

[9] Stufflebeam and Shinkfield, "Evaluación sistemática," Paidos. Barcelona, 1993.

[10] Cronbach, Course Improvement through Evaluation, New York: Teachers College Record, 1963.

[11] Triffin and Rajasingham,"En busca de la clase virtual. La educación en la sociedad de la información," Ediciones Paidós Ibérica, Barcelona, Madrid: S.A, 1997.

[12] E. Barbera, "La educación en red," Actividades Virtuales de Enseñanza y Aprendizaje, España: Paidós, 2004.

[13] M. Llarena and M. Paparo. (2006). Propuesta de una metodología de seguimiento y evaluación de cursos a distancia. Revista Iberoamericana de Educación. [Online]. Available: http://www.rieoei.org/deloslectores/1172Francisco.pdf.

[14] P. Kirschner, "Can we support CSCL? Education social and technological affordances for learning," in P. A. Kirschner, Ed., Three Worlds of CSCL: Can Support CSCL, Heerlen: Open University of the Netherlands, pp. 7-47, 2002.

[15] C. Coll, "Aprender y enseñar con las TIC: Expectativas, realidad y potencialidades," Boletín de la Institución Libre de Enseñanza, vol. 72, pp. 17-40, 2008.

[16] JISC, "Effective assessment in a digital age: A guide to technology-enhanced assessment and feedback," England: Higher Education Funding Council for England (HEFCE) on behalf of JISC, 2010.

[17] F. Díaz and G. Hernández, Estrategias Docentes Para un Aprendizaje Significativo: Una Interpretación Constructivista, Bogotá: McGraw Hill, 2010.

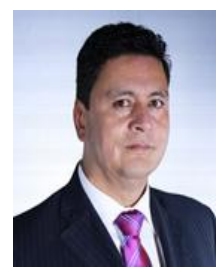

López M. Javier is from Bogotá, Colombia. He was born on April 21, 1968. He is specialized in advertising communication form Unilatina, Colombia from 2002. He got his master's degree in new technologies of information and communication from Universidad Nacional de Educación a Distancia, and PhD student in network education. His research interest is focused on e-learning.

He has worked in different Universities, for example, Universidad Nacional Abierta y a Distancia (UNAD), and Universidad Manuela Beltrán (UMB). He has held positions as the coordinator and the director of Educational Media Center, the director of Virtual Unity and Academic vice Rector. He has published "Seminario de evaluación para cursos virtuales de nivel superior". 